\title{
Hormone Measurement
}

National Cancer Institute

\section{Source}

National Cancer Institute. Hormone Measurement. NCI Thesaurus. Code C74742.

The determination of the amount of hormone present in a sample. 